Penelitian

\title{
Preparasi Strip Imunokromatografi Koloid Emas untuk Deteksi Cepat Aeromonas hydrophila
}

\section{Preparation of Colloidal Gold Immunochromatographic Strip for Rapid Detection of Aeromonas hydrophila}

\author{
Suherman ${ }^{1,2^{*}}$, Retno Damayanti ${ }^{3}$, Agustin Indrawati ${ }^{3^{*}}$ \\ ${ }^{1}$ Loka Pemeriksaan Penyakit Ikan dan Lingkungan Serang \\ ${ }^{2}$ Mahasiswa Pascasarjana Bioteknologi, Sekolah Pascasarjana, IPB University \\ ${ }^{3}$ Departemen Ilmu Penyakit Hewan dan Kesehatan Masyarakat Veteriner, Fakultas Kedokteran Hewan, IPB \\ University \\ *Penulis untuk korespondensi: ojssuherman@gmail.com, titin.seta@gmail.com \\ Diterima 12 Agustus 2020, Disetujui 2 November 2020
}

\begin{abstract}
ABSTRAK
Aeromonas hydrophila merupakan agen penyebab Motile Aeromonas Septicaemia (MAS) yang menyebabkan kerugian ekonomi pada industri akuakultur air tawar. Saat ini, metode diagnostik yang tersedia untuk determinasi A. hydrophila membutuhkan waktu lama dan tidak sesuai diaplikasikan di lapangan. Oleh karena itu, dibutuhkan adanya metode lain yang dapat digunakan sebagai diagnostik cepat dan aplikatif di lapangan. Tujuan dari penelitian ini adalah membuat alat diagnostik yang mampu digunakan sebagai pendeteksi agen penyebab MAS. Secara singkat, partikel koloid emas berukuran $31,88 \mathrm{~nm}$ dibuat melalui reduksi kimia asam kloroaurat dengan natrium sitrat. Koloid emas sebagai detektor dikonjugasikan dengan antibodi poliklonal anti A. hydrophila $50 \mu \mathrm{g} / \mathrm{ml} \mathrm{pada} \mathrm{pH}$ 7. Membran nitroselulosa sebagai membran reaksi, ditetesi dengan antibodi poliklonal anti $A$. hydrophila $2 \mathrm{mg} / \mathrm{ml} \mathrm{di}$ garis $T$ dan antibodi goat anti-rabbit IgG $1 \mathrm{mg} / \mathrm{ml}$ di garis C. Hasil dari penelitian ini, strip imunokromatografi yang dikembangkan mampu mendeteksi $A$. hydrophila dengan deteksi minimum $1,2 \times 10^{5} \mathrm{CFU} / \mathrm{ml}$. Strip bersifat spesifik terhadap A. hydrophila, tidak ada reaksi silang yang ditemukan ketika direaksikan dengan bakteri lain. Analisis sampel menggunakan strip hanya membutuhkan waktu 10 menit. Strip imunokromatografi yang dikembangkan dapat mendeteksi $A$. hydrophila dengan cepat dan memiliki potensi untuk digunakan di lapangan.
\end{abstract}

Kata Kunci : imunokromatografi, koloid emas, deteksi cepat, Aeromonas hydrophila

\begin{abstract}
Aeromonas hydrophila is known as a causative agent of Motile Aeromonas Septicaemia (MAS), causing severe economic losses in the freshwater aquaculture industry. At present, the available diagnostic methods for the determination of A. hydrophila require a long time and are not suitable for application in the field. Therefore, another method that can be used as a rapid and applicable diagnostic in the field are necessary. The aims of this research is to develop a diagnostic tool that is capable for a causative agent of MAS detection. Briefly, gold colloidal particles with a size of about $31.88 \mathrm{~nm}$ were prepared by chemical reduction of chloroauric acid with sodium citrate. Colloidal gold as a detector was conjugated with anti-A. hydrophila polyclonal antibodies $50 \mu \mathrm{mg} / \mathrm{ml}$ at $\mathrm{pH} 7$. Nitrocellulose membrane as a reaction membrane, coated with polyclonal antibody against $A$. hydrophila $2 \mathrm{mg} / \mathrm{ml}$ at $T$ line and anti-rabbit IgC antibody $1 \mathrm{mg} / \mathrm{ml}$ at line $C$. Result shows that developed immunochromatographic strips are able to detect $A$. hydrophila with a limit detection of $1,2 \times 10^{5} \mathrm{CFU} / \mathrm{ml}$. The strip is specific to $A$. hydrophila, no cross-reactions was found when reacting with other bacteria. It takes 10 minutes for the strip to analyze the sample. Developed immunochromatographic strip could detect $A$. hydrophila quickly and potentially to be used in the field.
\end{abstract}

Keywords : immunocromatographic, colloidal gold, rapid detection, Aeromonas hydrophila 


\section{PENDAHULUAN}

Penyakit Motile Aeromonas Septicaemia (MAS) menjadi faktor penghambat dalam perkembangan industriakuakultur. Penyakit yang disebabkan oleh Aeromonas hydrophila ini mengakibatkan kerugian ekonomi pada komoditas ikan air tawar (Pang et al., 2015). Motile Aeromonas Septicaemia menjadi masalah yang menonjol dalam percepatan industri akuakultur di Asia Tenggara dan wilayah lain di dunia. Di Indonesia, penyakit ini sudah mewabah sejak tahun 1980 pada ikan lele (Clarias sp.) (Angka et al., 1995), dan sampai saat ini masih sering dijumpai serangan penyakit ini. Pengendalian, pemantauan dan lalu lintas agen penyakit ini harus ketat dilakukan. Teknologi cepat, sederhana, sensitif, serta hemat biaya sangat penting sebagai metode untuk mendeteksi bakteri ini.

Determinasi A. hydrophila sampai saat ini didasarkan pada uji biokimia, Polymerase Chain Reaction (PCR), Enzyme-Linked Immunosorbent Assay (ELISA), Agar Gel Precipitation Test (AGPT) atau reaksi aglutinasi. Metode-metode tersebut sensitif dan akurat, namun membutuhkan tenaga terampil, hasil uji lama, dan tidak representatif diaplikasikan di lapangan. Deteksi cepat A. hydrophila menggunakan strip imunokromatografi merupakan pilihan metode yang tepat, aplikatif, mudah digunakan, waktu pengujian singkat, dan memiliki potensi digunakan di lapangan.

Strip imunokromatografi sudah banyak digunakan untuk mendeteksi antibiotik, toksin, bakteri dan virus (Ngom et al., 2010). Strip yang menggunakan label koloid emas telah dikembangkan dan diterapkan sebagai alat deteksi bakteri patogen pada hewan akuatik, seperti Edwardsiella tarda, Streptococcus agalactiae dan Edwarsiella ictaluri (Liu et al., 2015; Wen-de et al., 2017; Li et al., 2018). Alat diagnostik ini belum dikembangkan untuk mendeteksi bakteri patogen penyebab MAS, oleh karena itu penelitian ini bertujuan untukmembuat strip imunokromatografi sebagai metode alternatif dalam mendeteksi $A$. hydrophila.

\section{BAHAN DAN METODE}

\section{Antibodi Anti A. hydrophila dan Bakteri Uji}

Antibodi anti A. hydrophila dan bakteri uji yang digunakan merupakan sampel arsip milik Loka Pemeriksaan Penyakit Ikan dan Lingkungan Serang.
Antibodi anti A. hydrophila tersebut adalah antibodi poliklonal yang telah dipurifikasi menggunakan Melon Gel IgG Spin Purification Kit. Bakteri uji yang terdiri A. hydrophila, Aeromonas caviae, Aeromonas sobria, E. tarda, S. agalactiae, Salmonella arizonae, dan Escherichia coli telah diidentifikasi menggunakan Vitek 2 Compact.

\section{Sintesis Koloid Emas}

Koloid emas disiapkan menggunakan metode Turkevich (Rohiman et al., 2014). Logam emas 0,1 g (kemurnian 99,99\%) dilarutkan ke dalam larutan aqua regia dan dipanaskan pada suhu $100{ }^{\circ} \mathrm{C}$ disertai pengadukan hingga volume larutan menjadi $10 \mathrm{ml}$, diperoleh larutan $1 \%$ asam kloroaurat $\left(\mathrm{HAuCl}_{4}\right)$. Selanjutnya larutan $0,01 \% \mathrm{HAuCl}_{4}$ dipanaskan pada suhu $220^{\circ} \mathrm{C}$ (suhu larutan $95^{\circ} \mathrm{C}$ ) dan diaduk sampai larutan menjadi homogen. Sepuluh menit kemudian, larutan $1 \%$ trisodium sitrat (w/v) sebanyak $5 \mathrm{ml}$ ditambahkan perlahan. Larutan diaduk dan terus dipanaskan sampai warna larutan berubah dari kuning terang, transparan, abu-abu, ungu tua dan merah anggur. Koloid emas yang dihasilkan didinginkan pada suhu kamar, selanjutnya difiltrasi menggunakan membran $0,45 \mu \mathrm{m}$. Penyimpanan dilakukan di tempat gelap dan suhu $4{ }^{\circ} \mathrm{C}$ hingga akan digunakan. Koloid emas dikarakterisasi menggunakan spektofotometer UV-Vis (Multiskan Sky Microplate Spectrophotometer, Thermo Fisher Scientific) dan ukuran partikel koloid emas dihitung menggunakan persamaan menurut Haiss et al. (2007), yaitu :

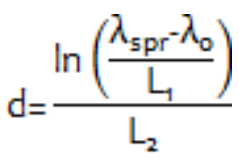

$\mathrm{d}=$ ukuran diameter partikel koloid emas

$\lambda_{\text {spr }}=$ panjang gelombang padaabsorbansi maksimum koloid emas

$\lambda_{0}=512$

$L_{1}=6,53$

$\mathrm{L} 2=0,0216$

Pembuatan Konjugat Antibodi Anti A. hydrophilaKoloid Emas

Pembuatan konjugat diawali dengan penentuan $\mathrm{pH}$ optimum koloid emas dan jumlah antibodi anti $A$. hydrophila dalam menstabilkan koloid emas. Optimasi pH koloid emas dilakukan dengan penambahan $0,1 \mathrm{M}$ potassium carbonate $\left(\mathrm{K}_{2} \mathrm{CO}_{3}\right) \mathrm{ke}$ dalam koloid emas, sehingga diperoleh nilai $\mathrm{pH}$ 
masing-masing koloid emas berturut-turut $6,7,8$ dan 9. Koloid emas dengan $\mathrm{pH}$ yang berbeda (200 $\mu \mathrm{l})$ pada masing-masing tabung ditambahkan antibodi anti $A$. hydrophila $0,1 \mathrm{mg} / \mathrm{ml}$ sebanyak $20 \mu \mathrm{l}$. Setelah bereaksi selama 15 menit, masing-masing tabung ditambahkan $20 \mu \mathrm{l} 10 \%$ natrium chloride $(\mathrm{NaCl})$. Lima menit kemudian, larutan diukur menggunakan spektofotometer UV-Vis pada panjang gelombang $525 \mathrm{~nm}$. Sampel yang menunjukkan absorbansi tertinggi dianggap sebagai reaksi optimum (Wen-de et al., 2017). Hal serupa dilakukan untuk menentukan jumlah antibodi anti $A$. hydrophila dalam mestabilkan koloid emas. Sebanyak 10 tabung diisi dengan 0,01 M Phosphate Buffered Saline (PBS) pH 7,4 sebanyak $40 \mu \mathrm{l}$. Kemudian $40 \mu \mathrm{l}$ antibodi anti $A$. hydrophila 2 $\mathrm{mg} / \mathrm{ml}$ ditambahkan ke dalam tabung 1 dan diencerkan serial hingga tabung 9, sedangkan tabung 10 tanpa antibodi anti $A$. hydrophila. Tiap tabung ditambahkan koloid emas sebanyak $200 \mu \mathrm{l}$. Lima belas menit setelah pencampuran, $10 \% \mathrm{NaCl}$ sebanyak $40 \mu \mathrm{l}$ ditambahkan ke dalam tiap tabung. Jumlah antibodi anti $A$. hydrophila dalam menstabilkan koloid emas dievaluasi dengan pengamatan perubahan warna larutan dari merah menjadi biru, dinyatakan sebagai titik akhir tidak terjadinya perubahan warna larutan dari merah menjadi biru (Shim et al., 2007).

Konjugasi antibodi anti $A$. hydrophila dengan koloid emas (Zhou et al., 2014) dilakukan dengan cara : sebanyak $1 \mathrm{ml}$ koloid emas $\mathrm{pH} 7$ ditambahkan antibodi anti $A$. hydrophila $50 \mu \mathrm{g}$. Setelah reaksi selama 30 menit, 0,01 M PBS $\mathrm{pH}$ 7,4 yang mengandung 10\% Bovine Serum Albumin (BSA) ditambahkan sedemikian hingga konsentrasi akhir BSA menjadi $1 \%$. Larutan dibiarkan bereaksi selama 15 menit, dan kemudian ditambahkan 5\% Polyethylene Glycol (PEG) hingga konsentrasinya menjadi 0,1\%. Selanjutnya disentrifugasi pada 14000 g selama 60 menit pada $4{ }^{\circ} \mathrm{C}$. Supernatan yang jernih dikeluarkan dengan hati-hati, dan pelet dicuci sebanyak 2 kali menggunakan 0,002 M PBS pH 7,4. Selanjutnya pelet diresuspensikan kembali menggunakan buffer penyimpan (0,002 M PBS pH 7,4 yang mengandung $1 \%$ BSA, 0,05\% PEG, $5 \%$ sukrosa dan $0,5 \%$ Tween 20) hingga volume menjadi $100 \mu \mathrm{l}$. Kemudian disimpan pada suhu $4{ }^{\circ} \mathrm{C}$ sampai digunakan.

\section{Perakitan dan Karekteristik Strip Imunokro- matografi}

Strip imunokromatografi dirakit sesuai dengan penjelasan Wen-de et al. (2017). Struktur dan rakitan strip imunokromatografi terdiri dari bantalan sampel, bantalan konjugat, membran nitroselulosa, bantalan penyerap, dan bantalan pendukung. Bantalan sampel, bantalan konjugat, membran nitroselulosa dan bantalan penyerap disatukan pada bantalan penunjang. Bantalan sampel, bantalan konjugat dan bantalan penyerap digunakan membran Fusion 5 (GE Healthcare Life Sciences), membran nitroselulosa digunakan Hybond ECL (GE Healthcare Life Sciences), dan bantalan penunjang digunakan kertas Polyvinyl Cloride (PVC). Sebelum perakitan, konjugat antibodi anti $A$. hydrophila-koloid emas sebanyak 0,5 $\mu \mathrm{l} /$ $\mathrm{mm}^{2}$ diendapkan pada bantalan konjugat. Membran nitroselulosa dilapisi antibodi anti $A$. hydrophila pada garis $\mathrm{T}(2 \mathrm{mg} / \mathrm{ml})$ dan antibodi goat anti-rabbit $\lg C$ (Sigma) pada garis C $(1 \mathrm{mg} / \mathrm{ml})$, masing-masing $0,1 \mu \mathrm{l} / \mathrm{mm}$ dengan jarak $5 \mathrm{~mm}$ antara keduanya menggunakan Linomat 5 CAMAG. Setelah itu dilakukan blocking dengan $2 \%$ kasein. Selanjutnya strip dipotong dengan ukuran $60 \mathrm{~mm} \times 4 \mathrm{~mm}$, diletakkan dalam kaset plastik dan disimpan dalam kantong plastik yang dilengkapi dengan desicant pada suhu $4{ }^{\circ} \mathrm{C}$ hingga akan dipergunakan.

Sampel yang mengandung $A$. hydrophila dengan kepadatan $1,2 \times 10^{8} \mathrm{CFU} / \mathrm{ml}$ diencerkan secara serial sampai dengan $1,2 \times 10^{1} \mathrm{CFU} / \mathrm{ml}$ dan dididihkan selama 30 menit. Sebanyak $150 \mu$ diteteskan untuk mengevaluasi sensitifitas strip, sedangkan spesifitas strip diverifikasi menggunakan sampel yang mengandung A. caviae, A. sobria, E. tarda, S. agalactiae, S. arizonae, dan E. coli. Hasil uji ditentukan berdasarkan adanya sinyal warna merah yang terbentuk pada garis $C$ dan $T$ secara bersamaan jika hasil uji positif, sedangkan hasil negatif jika sinyal warna merah hanya pada garis $C$.

\section{Analisis Data}

Seluruh data yang diperoleh dari penelitian ini dianalisa secara deskriptif dan disajikan dalam bentuk tabel dan gambar.

\section{HASIL}

Hasil sintesis koloid emas yang akan digunakan sebagai detektor pada penelitian ini memiliki warna merah anggur. Karakteristik koloid emas tersebut didasarkan pada puncak serapan panjang gelombangnya $\left(\lambda_{\text {maks }}\right)$ menggunakan spektrofotometer UV-Vis dan ukuran partikel koloid emas dapat ditentukan. Hasil penelitian menunjukkan bahwa puncak serapan koloid emas pada panjang gelombang 
$525 \mathrm{~nm}$ (Gambar 1, garis merah) dan partikel koloid emas diperkirakan berukuran 31,88 nm. Selanjutnya koloid emas tersebut digunakan dalam menyiapkan konjugat antibodi anti $A$. hydrophila-koloid emas sebagai reagen pembuatan strip imunokromatografi. Setelah koloid emas dikonjugasikan dengan antibodi anti $A$. hydrophila terjadi sedikit pergeseran puncak serapan koloid emas pada panjang gelombang $532 \mathrm{~nm}$ dengan puncakutama yang lebih lebar dan nilai serapan lebih kecil (Gambar 1, garis biru).

Nilai pH koloid emas dan jumlah antibodi anti $A$. hydrophila dalam mestabilkan koloid emas sangat menentukan keberhasilan konjugasi. Hasil penelitian menunjukkan bahwa koloid emas dengan $\mathrm{pH} 7$ (Gambar 2A) merupakan pH optimum koloid emas untuk konjugasi. Koloid emas dengan $\mathrm{pH} 7$ memberikan nilai absorbansi tertinggi yaitu 0,075 dibandingkan dengan koloid emas pada $\mathrm{pH} 6, \mathrm{pH} 8$ dan $\mathrm{pH}$ 9. Warna yang dimiliki koloid emas $\mathrm{pH} 7$ lebih stabil dan intensitas warna merah yang lebih tajam (Gambar 2B). Antibodi anti A. hydrophila sebesar 12,5 $\mu$ g merupakan konsentrasi yang dapat menstabilkan $1 \mathrm{ml}$ koloid emas pada $\mathrm{pH}$ optimumnya (Tabel 1). Hasil penelitian menunjukkan bahwa pada konsentrasi ini tidak terjadi perubahan warna dari merah ke biru, sedangkan pada konsentrasi yang lebih kecil mengalami perubahan warna (Gambar 3).

Perakitan strip imunokromatografi pada penelitian ini dilakukan setelah komponen utama strip dioptimasi. Sebelum ditetesi konjugat antibodi anti $A$. hydrophila-koloid emas, bantalan konjugat direndam dalam 0,01 M PBS pH 7,4 yang mengandung 0,05\% Tween 20 dan 10\% sukrosa selama 10 menit, selanjutnya dikeringkan pada suhu ruang.
Hal serupa dilakukan terhadap bantalan sampel, sedangkan membran nitroselulosa yaitu konsentrasi antibodi goat anti-rabbit lg $G$ pada garis $C$ dan antibodi anti $A$. hydrophila pada garis $T$ ditentukan terlebih dahulu. Hasil optimasi garis C (Gambar 4A), konsentrasi $1 \mathrm{mg} / \mathrm{ml}$ dari antibodi goat anti-rabbit IgG sudah memberikan warna merah sangat jelas, selanjutnya digunakan di garis $C$ untuk optimasi garis $T$. Konsentrasi antibodi anti $A$. hydrophila di garis $T$ sebesar $2 \mathrm{mg} / \mathrm{ml}$ memberikan sinyal warna merah yang lebih jelas dibanding $1 \mathrm{mg} / \mathrm{ml}$ dan 0,5 $\mathrm{mg} / \mathrm{ml}$ (Gambar 4B). Kedua konsentrasi antibodi pada garis $C$ dan $T$ tersebut diaplikasikan pada membran nitroselulosa saat perakitan strip.

Berdasarkan hasil pengujian menggunakan strip imunokromatografi yang dikembangkan pada penelitian ini, memberikan hasil uji positif terhadap A. hydrophila. Sampel yang digunakan dalam pengujian merupakan suspensi bakteri $A$. hydrophila sebanyak $150 \mu$ l dengan konsentrasi $1,2 \times 10^{8} \mathrm{CFU} / \mathrm{ml}$ dan diteteskan di tempat sampel pada strip (Gambar 5). Tidak ditemukan reaksi silang dengan bakteri lain pada aplikasi strip. Bakteri tersebut diantaranya adalah A. caviae, A. sobria, E. tarda dan S. agalactiae. Bakteri tersebut merupakan bakteri patogen yang hidup di lingkungan perairan dan sering menginfeksi ikan.

Sensitifitas strip imunokromatografi yang dikembangkan ditentukan dengan menguji suspensi bakteri $A$. hydrophila pada konsentrasi yang berbeda. Hasil penelitian menunjukkan strip dapat mendeteksi $A$. hydophila dengan deteksi minimum pada $1,2 \times 10^{5} \mathrm{CFU} / \mathrm{ml}$, konsentrasi $A$. hydrophia dibawah $1,2 \times 10^{5} \mathrm{CFU} / \mathrm{ml}$ tidak dapat dideteksi oleh strip (Gambar 6). Aplikasi strip dalammenganalisa

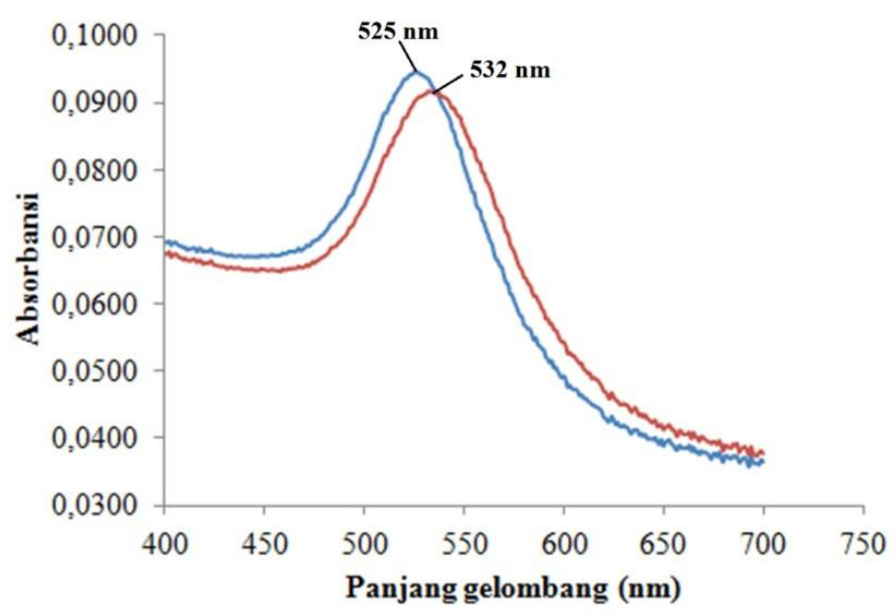

Gambar 1 Spektrum koloid emas (garis merah)dan konjugat antibodi anti A. hydrophila-koloid emas (garis biru) 

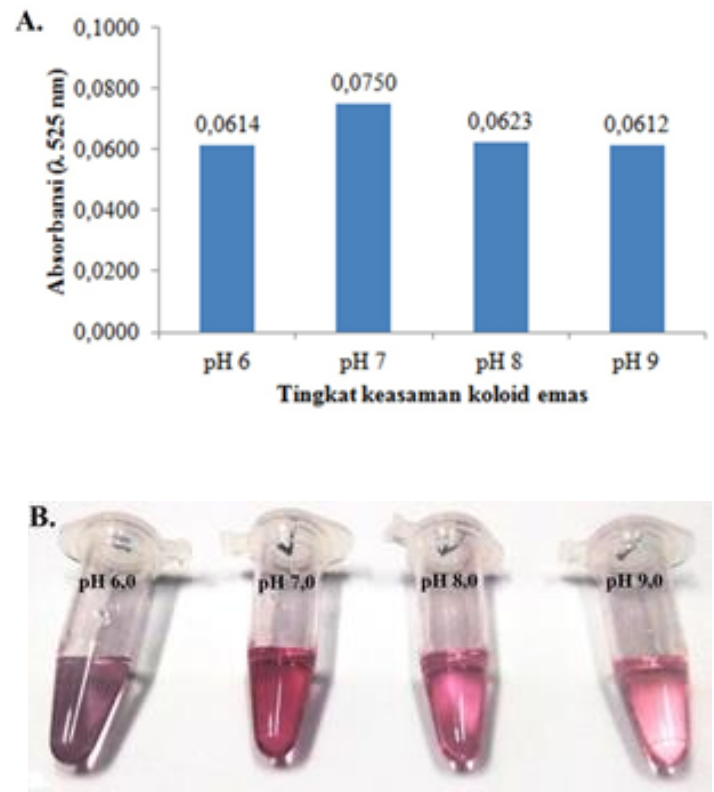

Gambar 2 Optimasi pH koloid emas untuk konjugasi. Keterangan: A. Nilai absorbansi koloid emas dengan $\mathrm{pH}$ berbeda pascakonjugasi; $\mathrm{B}$. Warna koloid emas dengan $\mathrm{pH}$ yang berbed a pasca konjugasi

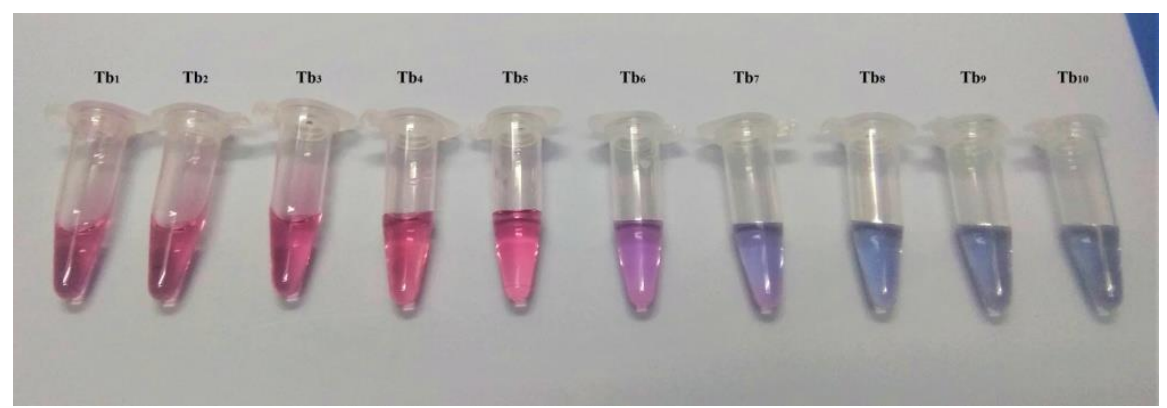

Gambar 3 Perubahan warna koloid emaspasca konjugasidengan berbagai konsentrasiantibodi. Keterangan: $\mathrm{Tb}_{1} \mathrm{~s} / \mathrm{d} \mathrm{Tb_{10 }}$ : Titrasi konsentrasi antibodi anti $A$. hydrophila untuk menstabilkan koloid emas

sampel pada penelitian ini diketahui bahwa sinyal warna merah di garis $\mathrm{T}$ dari setiap strip terbentuk setelah 2-3 menit, sedangkan di garis $C$ setelah 4-5 menit dan mencapai bantalan penyerap setelah 10 menit. Hasil perhitungan waktu tersebut ditetapkan sebagai waktuyang dibutuhkan strip dalam menyelesaikan pengujian terhadap sampel, baik hasil uji positif maupun negatif terhadap A. hydrophila.

\section{PEMBAHASAN}

Reaksi antigen dengan antibodi merupakan reaksi yang tidak kasat mata, oleh karena itu sangat penting dilakukan pelabelan menggunakan senyawa pada reaksi tersebut. Senyawa label merupakan senyawa yang dikonjugasi padaantigen atau antibodi, berupa enzim, senyawa berfluoresensi, senyawa luminescence, partikel, radioaktif, dan sebagainya. Konjugasi antara senyawa label dengan antigen atau antibodi akan memberikan visualisasi terjadinya reaksi antigen dengaan antibodi. Salah satu yang umum digunakan sebagai label pada strip imunokromatografi adalah koloid emas. Koloid emas dapat diterapkan dalam immunoassay, biosensor, terapi gen, dan komputasi DNA (Shim etal., 2007). Koloid emas dapat disintesis secara kimia, dengan mereduksi emas dalam bentuk garamnya (Rohiman et al., 2014).

Koloid emas yang digunakan dalam penelitian ini merupakan hasil sintesis menggunakan logam emas $\mathrm{A} \mathrm{Au}$ ) yang direduksi menggunakan sodium sitrat. 
Tabel 1 Titrasi konsentrasi antibodi anti A. hydrophila untuk menstabilkan $1 \mathrm{ml}$ koloid emas

\begin{tabular}{ccccc}
\hline Tabung & $\begin{array}{c}\text { Pengenceran } 40 \mu \mathrm{l} \\
\text { antibodi } 2 \mathrm{mg} / \mathrm{ml}\end{array}$ & $\begin{array}{c}\text { Konsentrasiantibodiper } \\
200 \mu \mathrm{k} \text { koloid emas } \\
(\mu \mathrm{g})\end{array}$ & $\begin{array}{c}\text { Konsentrasi antibodi } \\
\text { per 1 ml koloid emas } \\
(\mu \mathrm{g})\end{array}$ & Warna \\
\hline $\mathrm{Tb}_{1}$ & $1 / 2$ & 40 & 200 & Merah \\
$\mathrm{Tb}_{2}$ & $1 / 4$ & 20 & 100 & Merah \\
$\mathrm{Tb}_{3}$ & $1 / 8$ & 10 & 50 & Merah \\
$\mathrm{Tb}_{4}$ & $1 / 16$ & 5 & 25 & Merah \\
$\mathrm{Tb}_{5}{ }^{*}$ & $1 / 32$ & 2,5 & 12,5 & Merah \\
$\mathrm{Tb}_{6}$ & $1 / 64$ & 1,25 & 6,25 & Ungu \\
$\mathrm{Tb}_{7}$ & $1 / 128$ & 0,625 & 3,13 & Biru \\
$\mathrm{Tb}_{8}$ & $1 / 256$ & 0,313 & 1,56 & Biru \\
$\mathrm{Tb}_{9}$ & $1 / 512$ & 0,156 & 0,78 & Biru \\
$\mathrm{Tb}_{10}$ & 0 & 0 & 0 & Biru \\
\hline
\end{tabular}

* : Titik akhir stabilitas koloid emas

Koloid emas hasil sintesis dengan metode ini digunakan sebagai label pada strip imunokromatografi yang dikembangkan. Karakteristik koloid emas dengan puncak serapan pada panjang gelombang $525 \mathrm{~nm}$ dengan ukuran partikel $30 \mathrm{~nm}$ telah dilaporkan (Rahme et al., 2013; Zeng et al., 2014; Berlina et al., 2019) dan banyak peneliti menggunakan koloid emas dengan ukuran partikel tersebut sebagai label pada pembuatan strip imunokromatografi (Sun et al., 2012; Liu et al., 2014; Ariffin et al., 2020). Koloid emas dengan ukuran partikel $31,88 \mathrm{~nm}$ pada penelitian ini memberikan kestabilan yang baik ketika dikonjugasikan dengan jumlah optimum antibodi anti $A$. hydrophila. Senyawa imunoreaksi dapat bergerak cepat pada membran nitroselulosa, warna yang ditunjukkan jelas dan mudah dibedakan.

Konjugasi antara antibodi dan koloid emas dapat terjadi melalui cross-linker atau adsorpsi langsung. Pada penelitian ini, antibodi terimobilisasi pada permukaan koloid emas melalui adsorpsi langsung. Adanya interaksi tersebut, gambaran spektrum UV$v$ is terhadap konjugat antibodi anti $A$. hydrophilakoloid emas menyebabkan pergeseran puncak serapan panjang gelombangnya ke arah pita merah (redshifting). Selain itu, puncak utama menjadi lebih lebar, sementara nilai serapan maksimumnya menjadi lebih kecil. Ini menunjukkan bahwa ukuran koloid emas yang terkonjugasi dengan antibodi anti $A$. hydrophila menjadi lebih besar dan ukuran koloid emas menjadi sedikit kurang seragam (Zhou et al., 2014).

Antibodi terikat kuat pada permukaan partikel koloid emas karena adanya gaya elektrostatik, koloid emas bermuatan negatif sedangkan antibodi bermuatan positif. Adsorpsi langsung protein ke permukaan emas tergantung pada $\mathrm{pH}$, titik isoelektrik dan konsentrasi protein. Titik isoelektrik antibodi adalah sekitar 7, sehingga antibodi dapat mempertahankan konfigurasi dan bioaktivitasnya pada kondisi $\mathrm{pH}$ yang dekat dengan titik isoelektriknya. Koloid emas dengan $\mathrm{pH} 7$ merupakan kondisi keasaman optimum untuk adsorpsi protein (Taghipour et al., 2018) dan dalam penelitian ini sangat sejalan dengan hal tersebut.

Jumlah minimum antibodi yang dapat menstabilkan $1 \mathrm{ml}$ koloid emas pada penelitian ini diketahui sebesar $12,5 \mu \mathrm{g}$, yaitu titik terakhir tidak terjadinya perubahan warna merah ke biru setelah penambahan $\mathrm{NaCl}$. Jumlah antibodi dibawah $12,5 \mu \mathrm{g}$ terjadi perubahan warna dari merah ke biru, yang mengindikasikan bahwa koloid emas tidak dapat distabilkan pada jumlah tersebut. Beberapa penelitian sebelumnya (Zhou et al., 2014; Wen-de et al., 2017; Ariffin et al., 2020) menetapkan jumlah 


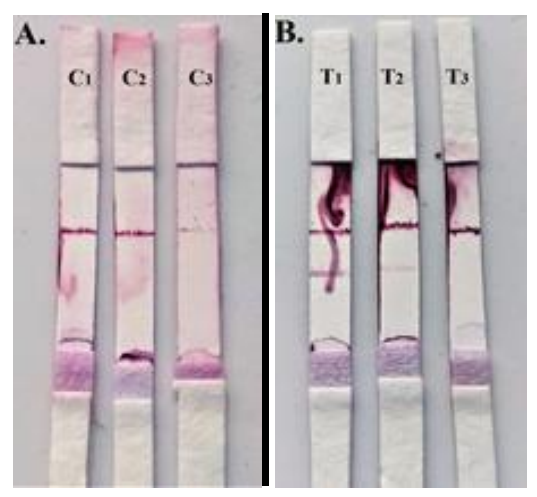

Gambar 4 Konsentrasi antibodi pada garis $C$ dan T. Keterangan: A. Konsentrasi antibodi goat anti-rabbit lg $\mathrm{C}$ pada garis $C\left(C_{1}: 2 \mathrm{mg} / \mathrm{ml} ; C_{2}: 1 \mathrm{mg} / \mathrm{ml} ; C_{3}: 0,5 \mathrm{mg} / \mathrm{ml}\right) ; B$. Konsentrasi antibodi anti $A$. hydrophila pada garis $\mathrm{T}\left(\mathrm{T}_{1}: 2 \mathrm{mg} / \mathrm{ml} ; \mathrm{T}_{2}: 1 \mathrm{mg} / \mathrm{ml} ; \mathrm{T}_{3}: 0,5 \mathrm{mg} / \mathrm{ml}\right)$ dengan antibodi goat anti-rabbit lg 1 $\mathrm{mg} / \mathrm{ml}$ pada garis $\mathrm{C}$

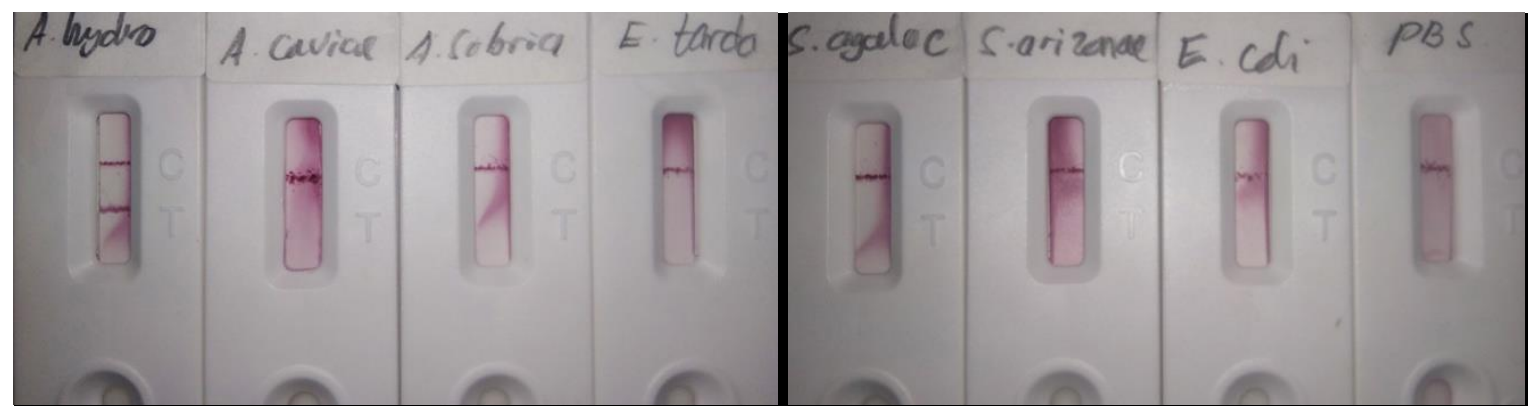

Gambar 5 Hasil uji reaksi silang strip dengan bakteri lain

antibodi yang diaplikasikan pada pembuatan konjugat adalah 1,2 kali jumlah minimum antibodi dalam mestabilkan koloid emas. Di dalam penelitian ini, konjugat yang diaplikasikan dengan 1,2 kali jumlah minimum antibodi memberikan warna yang tipis dan hampir tidak terlihat dengan mata telanjang pada garis uji (data tidak ditampilkan). Secara singkat, dalam penelitian ini konjugat disiapkan menggunakan jumlah antibodi anti $A$. hydrophila $50 \mu \mathrm{g}$ dalam $1 \mathrm{ml}$ koloid emas (empat kali dari jumlah minimum). Jumlah antibodi anti $A$. hydrophila ini memberikan hasil yang lebih baik saat penangkapan ikatan komplek antigen-konjugat antibodi anti A. hydrophila-koloid emas oleh antibodi penangkap di garis uji. Warna yang terbentuk lebih jelas dan mudah dilihat dengan kasat mata. Hal serupa juga telah dilaporkan, bahwa jumlah antibodi sebesar empat kali dari jumlah minimum digunakan dalam pembuatan konjugat antibodi anti E. tarda sebagai reagen yang diaplikasikan pada pembuatan strip imunokromatografi (Safrullah, 2016).

Penambahan PEG dan BSA pada konjugat diperlukan untuk menutup situs kosong di permukaan partikel emas sehingga kestabilan sistem tetap terjaga. Adanya situs kosong pada permukaan partikel koloid emas yang tidak diisi antibodi setelah konjugasi, sangat memungkinkan protein lain menempel pada permukaan partikel dan berpengaruh terhadap hasil pengujian. Kedua agen penstabil tersebut paling umum digunakan dalam pemblokiran situs permukaan koloid emas dalam pembuatan kit imunokromatografi (Li et al., 2018). Selain PEG dan BSA, tween 20 dan sukrosa ditambahkan pada konjugat sebagai agen pelarut kembali terhadap konjugat antibodi-koloid emas. Kombinasi tween 20 dan sukrosa berperan dalam pelepasan antibodi yang terkonjugasi dengan koloid emas kering pada bantalan konjugat. Sukrosa, ketika dikeringkan bersama koloid emas pada permukaan membran membetuk hydrated glaze sehingga akan mudah dan cepat larut jika bereaksi dengan suspensi sampel. Kehadiran sukrosa juga melindungi konjugat agar tidak lengket secara permanen ke permukaan membran setelah dikeringkan (Chiao et al., 2004). Tween 20 dapat membantu mengurangi perbedaan intensitas cairan pada membran, merupakan surfaktan yang membuat cairan bergerak lebih cepat dan mempersingkat waktu pengujian. 


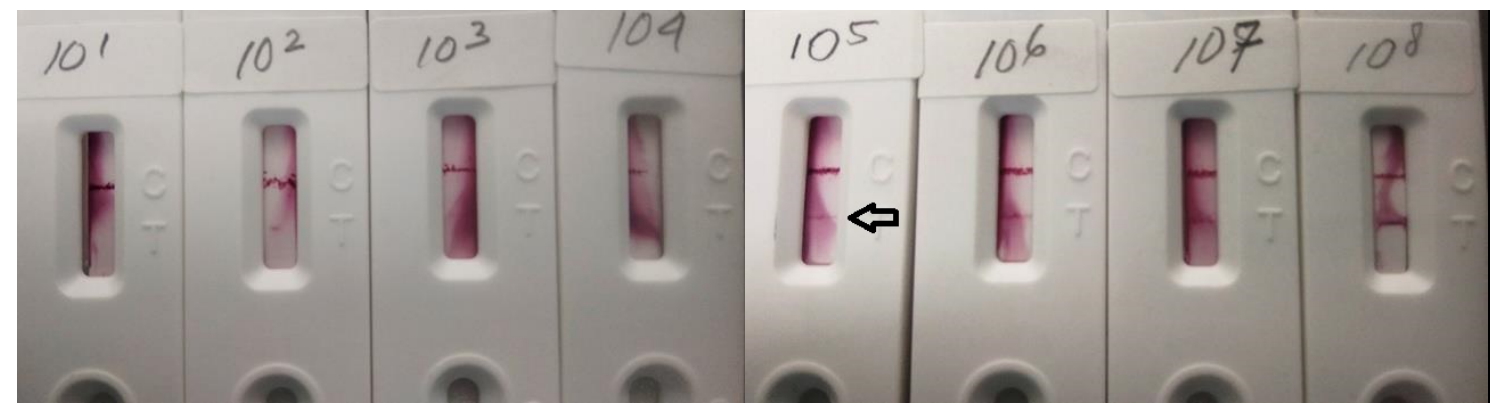

Gambar 6 Sensitifitas strip dalam mendeteksi A. hydrophila pada kepadatan $1,2 \times 10^{1} \mathrm{CFU} / \mathrm{ml} \mathrm{s} / \mathrm{d} 1,2 \times 10^{8}$ $\mathrm{CFU} / \mathrm{ml}$. Keterangan: tanda panah menunjukkan deteksi minimum strip $\left(1,2 \times 10^{5} \mathrm{CFU} / \mathrm{ml}\right)$

Pengembangan strip imunokromatografi pada penelitian ini menggunakan model sandwich. Strip imunokromatografi ini sangat cocok digunakan untuk mendeteksi target berupa makromolekul seperti protein dan memiliki beberapa epitope (Wang et al., 2018). Konsentrasi antibodi goat antirabbit lgG $1 \mathrm{mg} / \mathrm{ml}$ di garis $C$ dan antibodi anti $A$. hydrophila $2 \mathrm{mg} / \mathrm{ml}$ di garis T diaplikasikan pada membran nitroselulosa pada penelitian ini. Strip imunokromatografi menggunakan model sandwich dengan konsentrasi antibodi pada garis $C$ dan $T$ yang sama telah dilaporkan untuk mendeteksi $E$. tarda (Liu et al., 2015). Membran nitroselulosa mengikat antibodi dengan mekanisme elektrostatis. Dipol dari ester nitrat berinteraksi dengan dipol dari ikatan peptida antibodi. Pengeringan membran pada suhu kamar bertujuan mengikat antibodi pada nitroselulosa (Chiao et al., 2004). Setiap situs aktif yang tersisa pada membran diblokir dengan perendaman dalam $2 \%$ kasein. Pemblokiran bertujuan untuk menghindari ikatan tidak spesifik pada membran yang berpengaruh pada hasil pengujian.

Deteksi keberadaan A. hydrophila pada sampel diterjemahkan oleh hasil uji pada strip imunokromatografi. Sampel yang diteteskan pada bantalan sampel akan mengalir menuju bantalan konjugat dan berakhir pada bantalan penyerap. Bantalan penyerap menangkap kelebihan sampel yang melewati garis $\mathrm{T}$ dan $\mathrm{C}$ pada membran nitroselulosa. Analit target berupa antigen $A$. hydrophila yang melewati bantalan konjugat akan berikatan pada bagian spesifik antibodi anti A. hydrophila berlabel koloid emas. Selanjutnya antigen yang terikat pada antibodi anti $A$. hydrophila berlabel koloid emas bermigrasi menuju membran nitroselulosa karena adanya kapilaritas membran. Antibodi anti $A$. hydrophia yang berada di garis $T$ menangkap antigen yang terikat pada antibodi anti
A. hydrophila berlabel koloid emas, hasilnya sinyal warna merah teramati di garis T. Kompleks antigenantibodi anti $A$. hydrophila berlabel koloid emas yang tidak tertangkap di garis T melanjutkan migrasinya melewati garis $C$ dan ditangkap oleh antibodi goat anti-rabbit lgG. Garis $C$ selalu menunjukkan sinyal warna merah sebagai tes validasi.

Strip imunokromatografi yang dikembangkan dalam penelitian ini bersifat spesifik hanya mengenali A. hydrophila sebagai target uji positif dan memiliki deteksi minimum yang sepadan dengan strip yang telah dikembangkan oleh penelitian-penelitian sebelumnya. Laporan pengem-bangan strip imunokromatografi dengan model sandwich untuk mendeteksi bakteriagen penyebab penyakit pada ikan memiliki limit deteksi $1 \times 10^{5} \mathrm{CFU} / \mathrm{ml}$ untuk E. tarda (Liu et al., 2015) dan $1,5 \times 10^{5} \mathrm{CFU} / \mathrm{ml}$ untukS. agalactiae (Wen-de et al., 2017). Berbeda dengan yang dilaporkan oleh $\mathrm{Li}$ et al. (2018), limit deteksi strip terhadap E. ictaluri sebesar $5 \times 10^{6} \mathrm{CFU} / \mathrm{ml}$ dengan menggunakan model yang sama.

Berdasarkan penelitian ini dapat disimpulkan bahwa strip imunokromatografi yang dikembangkan mampu mendeteksi $A$. hydrophila secara spesifik. Deteksi minimum strip pada kepadatan bakteri $A$. hydrophila sebesar $1,2 \times 10^{5} \mathrm{CFU} / \mathrm{ml}$ dan waktu analisa hanya 10 menit.

\section{UCAPAN TERIMA KASIH}

Ucapan terima kasih penulis sampaikan kepada Kementerian Kelautan dan Perikanan atas dukungan dana penelitian melalui Pusat Pendidikan Kelautan dan Perikanan, Badan Riset dan Sumber Daya Manusia Kelautan dan Perikanan, serta Loka Pemeriksaan Penyakit Ikan dan Lingkungan Serang yang telah memfasilitasi pelaksanaan penelitian ini. 
"Penulis menyatakan tidak ada konflik kepentingan dengan pihak-pihak yang terkait dalam penelitian ini".

\section{DAFTAR PUSTAKA}

Angka SL, Lam TJ, Sin YM. 1995. Some virulence characteristics of Aeromonas hydrophila in walking catfish (Clarias gariepinus). Aquaculture 130:103-112.

Ariffin N, Yusof NA, Abdullah J, Abd Rahman SF, Ahmad Raston NH, Kusnin N, Suraiya S. 2020. Lateral flow immunoassay for naked eye detection of Mycobacterium tuberculosis. Journal of Sensors 2020: 1-10.

Berlina AN, Komova NS, Zherdev A V., Gaur MS, Dzantiev BB. 2019. Colorimetric technique for antimony detection based on the use of gold nanoparticles conjugated with poly-A oligonucleotide. Applied Sciences 9: 1-14.

Chiao DJ, Shyu RH, Hu CS, Chiang HY, Tang SS. 2004. Colloidal gold-based immunochromatographic assay for detection of botulinum neurotoxin type B. Journal of Chromatography B 809: 37-41.

Haiss W, Thanh NTK, Aveyard J, Fernig DG. 2007. Determination of size and concentration of gold nanoparticles from UV-Vis Spectra. Analytical Chemistry 79:4215-4221.

Li R, Zhang X, Yang C, Ye S, Li H, Li Q. 2018. Development of a colloidal gold-based immunochromatographic assay for the rapid detection of Edwardsiella ictaluri. Journal of Nanoscience and Nanotechnology 18: 3800-3805.

Liu H, Wang Y, Xiao J, Wang Q, Liu Q, Zhang Y. 2015. An immunochromatographic test strip for rapid detection of fish pathogen Edwardsiella tarda. Bioresources and Bioprocessing 2: 1-8.

Liu L, Luo L, SuryoprabowoS, Peng J, Kuang H, Xu C. 2014. Development of an immunochro-matographic strip testfor rapid detection of ciprofloxacin in milk samples. Sensors 14: 16785-16798.

Ngom B, Guo Y, Wang X, Bi D. 2010. Development and application of lateral flow test strip technology for detection of infectious agents and chemical contaminants: A review. Anal Bioanal Chem 397:1113-1135.

Pang $M$, Jiang J, Xie X, Wu Y, Dong Y, Kwok AHY, Zhang W, Yao H, Lu C, Leung FC, Liu Y. 2015. Novel insights into the pathogenicity of epidemic Aeromonas hydrophila ST251 clones from comparative genomics. Scientific Reports 5:1-15. Rahme K, Nolan MT, Doody T, McGlacken GP, Morris
MA, O'Driscoll C, Holmes JD. 2013. Highly stable PEGylated gold nanoparticles in water: Applications in biology and catalysis. RSC Advances 3: 2101621024.

Rohiman A, Buchari, Amran MB, Juliastuti E, Idris I. 2014. Sintesis, karakterisasi, dan aplikasi gold nanoparticles (AuNPs) pada pertumbuhan silicon nanowires (SiNWs). Research and Development on Nanotechnology in Indonesia 1: 74-82.

Safrullah. 2016. Pembuatan Prototipe Kit Imunokromatografi untuk Mendeteksi Antigen Edwardsiella tarda. Tesis S2. Sekolah Pascasarjana, Institut Pertanian Bogor. Bogor. p40-55.

Shim WB, Yang ZY, Kim JS, Kim JY, Kang SJ, Woo GJ, Chung YC, Eremin SA, Chung DH. 2007. Development of immunochromatography striptest using nanocolloidal gold-antibody probe for the rapid detection of aflatoxin B1 in grain and feed samples. Journal of Microbiology and Biotechnology 17: 1629-1637.

Sun F, Liu L, Ma W, Xu C, Wang L, Kuang H. 2012. Rapid on-site determination of melamine in raw milk by an immunochromatographic strip. International Journal of Food Science and Technology 47: 1505-1510.

Taghipour YD, Kharrazi S, Amini SM. 2018. Antibody conjugated gold nanoparticles for detection of small amounts of antigen based on surface plasmon resonance(SPR) spectra. Nanomed Res J 3: 102-108.

Wang C, Peng J, Liu DF, Xing KY, Zhang GG, Huang Z, Cheng S, Zhu FF, Duan ML, Zhang KY, Yuan MF, Lai WH. 2018. Lateral flow immunoassay integrated with competitive and sandwich models for the detection of aflatoxin $\mathrm{M}_{1}$ and Escherichia coli O157:H7 in milk. Journal of Dairy Science 101: 8767-8777.

Wen-de W, Min L, Ming C, Li-ping L, Rui W, Hai-lan C, Fu-Yan C, Qiang M, Wan-wen L, Han-zhong C. 2017. Development of a colloidal gold immunochromatographic strip for rapid detection of Streptococcus agalactiae in tilapia. Biosensors and Bioelectronics 91: 66-69.

Zeng Q, Shao D, Ji W, Li J, Chen L, Song J. 2014. The nanotoxicity investigation of optical nanoparticles to cultured cells in vitro. Toxicology Reports 1:137-144.

Zhou C, Zhang X, Huang X, Guo X, Cai Q, Zhu S. 2014. Rapid detection of chloramphenicol residues in aquatic products using colloidal gold immunochromatographic assay. Sensors 14: 21872-21888. 